\title{
Expanding the Role of Povidone-iodine in a COVID-19 Era
}

\author{
Jesse Pelletier
}

Ocean Ophthalmology Group, North Miami Beach, FL, USA

DOI: https://doi.org/10.17925/USOR.2020.13.2.61

$\mathrm{T}$ he COVID-19 pandemic has brought fundamental changes to the practice of medicine. As a more robust understanding of severe acute respiratory syndrome coronavirus 2 is elucidated, practices will require greater flexibility in order to adapt. Antiseptics, such as povidone-iodine (PVP-I), are now routinelyemployed and will play agreater role in the future of healthcare. Due to its ability to protect both patients and healthcare providers alike, PVP-I utilization, in the form of oral and nasal solutions, should be considered as an additional and expansive step in the standard precautions algorithm.

\section{Keywords}

COVID-19, SARS-CoV-2, antiseptics, povidone-iodine, decontamination, antiviral

Disclosure: The author has no financial or non-financial relationships or activities to declare in relation to this article. Review Process: Double-blind peer review.

Compliance with Ethics: This article is an opinion piece and does not report on new clinical data, or any studies with human or animal subjects performed by the author.

Authorship: The named author meets the International Committee of Medical Journal Editors (ICMJE) criteria for authorship of this manuscript, takes responsibility for the integrity of the work as a whole, and has given final approval for the version to be published.

Access: This article is freely accessible at touchOPHTHALMOLOGY.com (c) Touch Medical Media 2020.

Received: June 2, 2020

Accepted: July 2, 2020

Published Online: August 12, 2020

Citation: US Ophthalmic Review. 2020;13(2):61-2

Corresponding Author: Jesse Pelletier,

Ocean Ophthalmology Group, 1400 NE Miami Gardens

Drive, Suite 203, North Miami Beach, FL 33179, USA

E: jesse.pelletier@oceanophthalmology.com

Support: No funding was received for

the publication of this article.
The coronavirus pandemic has swept the globe, exposing healthcare systems trying to deal with this formidable public health crisis. Since the beginning of the outbreak, ophthalmologists have played a pivotal role. In China, they were among the first to recognize the emergence of the virus, and have sadly been counted as some of the earliest casualties among medical doctors. As this crisis unfolded, drastic changes in the routine practice of medicine were essential as an up-close understanding of transmission dynamics was realized. Non-essential office visits/procedures were suspended, and disrupted workflow led to the utilization of new, virtual technologies to address patient needs. All the while, physicians across specialties struggled to build consensus opinions on the best approach to patient care, while grappling with an incomplete understanding of a novel pathogen. Now that some of these restrictions have loosened and outpatient clinics/ambulatory surgery centers reopen, ophthalmologists find themselves at the intersection of expanding care, while trying to protect themselves and their patients.

Fortunately, much has been learned about COVID-19 in a short period of time. Building upon an understanding imparted by experience with coronavirus, specifically those strains causing severe acute respiratory syndrome (SARS) and Middle East respiratory syndrome, it is understood that human-to-human transmission occurs mainly through family members and nosocomial spread. Although exact mechanisms remain elusive, droplet, airborne, feces, direct and indirect spread, and ocular fluids play a role. ${ }^{2,3}$ Much attention has been focused on the importance of personal protective equipment. Building on the fundamentals of standard precautions, it has been suggested that an effective strategy must be tripartite in nature. In order to successfully impede transmission in an outpatient setting, one should not only include appropriate personal protective equipment, but also environmental and administrative protocols. ${ }^{4}$

Ophthalmologists are at risk of contracting severe acute respiratory syndrome coronavirus 2 (SARS-CoV-2) because of close, sustained contact with patients, high volume, and the performing of procedures that induce aerosols. There is a paucity of descriptive data regarding COVID-19 eye findings; however, cases of conjunctivitis and keratoconjunctivitis have been reported. ${ }^{5-7}$ Similar to other viruses that are found in tears, such as adenovirus, herpes simplex virus, influenza, and SARS-Cov; SARS-CoV-2 has been identified in ocular secretions. ${ }^{2,8-10}$ Studies have generally demonstrated a poor correlation between active COVID-19 and its presence in tears. A recent manuscript positively identified the presence of both angiotensin-converting enzyme 2 (ACE2) and transmembrane serine protease 2 on the ocular surface. ${ }^{11}$ The full extent of these findings with respect to the susceptibility of the eye as a portal of entry, ocular surface as a reservoir of infectious virion, and the eye's interconnection to the nasopharynx are yet to be fully elucidated.

While it is possible to transmit through ocular exposure, a more concerning correlation is the high activity of the virus in saliva and the nasopharynx. One study detected viral copies present in the saliva of $91.7 \%$ of patients with COVID-19.12 The upper respiratory tract is specifically susceptible to 
infection by the SARS-COV-2 virus. 13,14 Levels of ACE2 are highest in nasal goblet and ciliated cells. ${ }^{15}$ This indicates that the upper airway may be preferentially infected early in the disease making these cells a potential reservoir for SARS-CoV-2 infection. Because SARS-CoV-2 is an enveloped virus, its release does not require cell lysis. The virus can exploit existing secretory pathways in the upper respiratory tract to induce low-level infection that generates virus-laden droplets and aerosols in patients with no overt pathology. ${ }^{16}$ These discoveries have clinical implications reaching beyond the current usage of face masks. They may provide clues to candidate targets for early-stage interventions.

This new era has expanded awareness and application of standard precautions. We have been taught that we should use a plain antimicrobial soap for routine hand-washing; however, the additional step of a water-based antiseptic for specific circumstances is now compulsory. It has become a routine part of our everyday behavior. The bulk of attention has been focused on alcohol-based hand sanitizer and its scarcity. This has led to at-home production, along with unconventional producers, such as distilleries and perfumeries, reappropriating traditional manufacturing to meet demand. However, the potential use of other antiseptics has been largely overlooked despite robust safety and efficacy data that have accumulated over decades.

Povidone-iodine (PVP-I) is a broad-spectrum antiseptic with no known resistance, that has been listed by the World Health Organization as an essential medicine. ${ }^{17}$ It is available in both developed and developing nations alike. PVP-I products have a long history of utility because of strong antiviral, antifungal, and antibacterial properties stemming from the harnessed potency of the halogen, iodine. ${ }^{18,19}$ PVP-I is broadly virucidal; a recently developed nasal/oral formulation has been shown to rapidly deactivate SARS-COV-2 in vitro. ${ }^{20}$

With respect to clinical data, PVP-I has been used safely in the nasal cavity, the sinuses, and orally to treat a variety of conditions. Dilute PVP-I sinonasal rinsing solution has been shown to be a safe and effective ancillary therapy for recalcitrant chronic rhinosinusitis. ${ }^{21}$ For oral decontamination, studies have shown that PVP-I gargle and mouthwash demonstrate strong bactericidal properties. ${ }^{22,23}$ Oral virucidal studies underscore its efficacy, reporting that it outperforms other antiseptics such as chlorhexidine and benzalkonium chloride. ${ }^{23,24}$ Gargling with PVP-I is common practice in Japan, and it is used for both the prevention and treatment of upper respiratory tract infections caused by influenza-like illnesses and the common cold. ${ }^{25}$ Gargling has been shown to decrease the transport of bacteria into the trachea. ${ }^{26}$ PVP-I rinsing of the oropharyngeal tissues prior to intubation leads to a lower rate of ventilation-associated pneumonia. ${ }^{27}$ These data support the notion that PVP-I may provide a protective oropharyngeal hygiene measure for individuals at high risk of exposure to oral and respiratory pathogens. It is currently produced abroad for use as a $1 \% \mathrm{~W} / \mathrm{W}$ mouthwash every 2-4 hours and as a $0.45 \%$ w/W "sore throat spray." ${ }^{28,29}$

Ophthalmologists have some experience utilizing therapies such as alcohols, halogen-based antiseptics, or mupirocin in the nares to diminish methicillin-resistant Staphylococcus aureus (MRSA) colonization prior to performing ophthalmic surgery. This approach should be expanded with PVP-I, and especially adopted when preparing patients for surgical procedures or in any other setting that may create aerosols. Furthermore, all medical personnel should consider routinely using PVP-I iodine nasal and oral preparations to decrease asymptomatic viral shedding, and to mitigate further disease spread. It is possible to create safe, effective, and comfortable protocols with repeat dosing of PVP-I, which may decrease the risk of transmission.

Much like the universal mask policy of "my mask protects you and your mask protects me," regular decontamination strategies will act with similar reciprocity. As it is accepted that one washes one's hands prior to donning gloves, so it should be accepted that one decontaminates the oral and nasal tissues prior to donning a mask. This pandemic has forced us to think beyond what is evidence-based, and has compelled us to use our experience and common sense. In doing so, the extra safeguard of antisepsis may provide the strongest weapon yet against this virus. $\square$
1. Guo YR, Cao QD, Hong Z, et al. The origin, transmission and clinical therapies on coronavirus disease 2019 (COVID-19) outbreak - an update on the status. Mil Med Res. 2020;7:11

2. Xia J, Tong J, Liu M, et al. Evaluation of coronavirus in tears and conjunctival secretions of patients with SARS-COV-2 infection. Med Virol 2020:92:589-94.

3. XU Y, Li X, Zhu B, et al. Characteristics of pediatric SARS-CoV-2 infection and potential evidence for persistent fecal vira shedding. Nat Med. 2020;26:502-5

4. Lai THT, Tang EWH, Chau SKY, et al. Stepping up infection control measures in ophthalmology during the novel coronavirus outbreak: an experience from Hong Kong. Graefes Arch Clin Exp Ophthalmol. 2020;258:1049-55.

5. Zhang $X$, Chen $X$, Chen $L$, et al. The evidence of SARS-CoV-2 infection on ocular surface. Ocul Surf. 2020:18:360-2.

6. Wu P, Duan F, Luo C, et al. Characteristics of ocular findings of patients with coronavirus disease 2019 (COVID-19) in Hubei Province, China. AMA Ophthalmol. 2020;138:575-8.

7. Cheema M, Aghazadeh H, Nazarali S, et al. Keratoconjunctivitis as the initial medical presentation of the novel coronavirus disease 2019 (COVID-19). Can J Ophthalmol. 2020;55:e125-29.

8. Tong T, Lai TS. The severe acute respiratory syndrome coronavirus in tears. Br J Ophthalmol. 2005:89:392.

9. Creager HM, Kumar A, Zeng H, et al. Infection and replication of influenza virus at the ocular surface. J Virol. 2018;92:e02192-17.

10. Ramchandani $\mathrm{M}$, Kong M, Tronstein E, et al. Herpes simplex virus type 1 shedding in tears and nasal and oral mucosa of healthy adults. Sex Transm Dis. 2016;43:756-60.

11. Zhou L, XU Z, Castiglione GM, et al. ACE2 and TMPRSS2 are expressed on the human ocular surface, suggesting susceptibility to SARS-CoV-2 infection. Ocul Surf. 2020;18:537-44.
12. To KK, Tsang OT, Yip CC, et al. Consistent detection of 2019 novel coronavirus in saliva. Clin Infect Dis. 2020;71:841-3.

13. Liu Y, Liao W, Wan L, et al. Correlation between relative nasopharyngeal virus RNA load and lymphocyte count disease severity in patients with COVID-19. Viral Immunol. 2020:10.1089/vim 2020.0062 do: 10.1089/vim 2020.0062 [Online ahead of print].

14. Hamming I, Timens W, Bulthuis ML, et al. Tissue distribution of ACE2 protein, the functional receptor for SARS coronavirus. A first step in understanding SARS pathogenesis. J Pathol. 2004;203:631-7.

15. Sungnak W. Huang N, Bécavin C, et al. SARS-CoV-2 entry factors are highly expressed in nasal epithelial cells together with innate immune genes. Nat Med. 2020;26:681-7.

16. Wei WE, Li Z, Chiew CJ, et al. Presymptomatic transmission of SARS-COV-2 - Singapore, January 23-March 16, 2020. MMWR Morb Mortal Wkly Rep. 2020;69:411-15.

17. World Health Organization. WHO Model List of Essential Medicines (19th List). Geneva, Switzerland: World Health Organization. 2015. Available at: www.who.int/medicines/ publications/essentialmedicines/en/ (acccessed August 10, 2020)

18. Berkelman RL, Holland BW, Anderson RL. Increased bactericidal activity of dilute preparations of povidone-iodine solutions. J Clin Microbiol. 1982;15:635-9.

19. Gottardi W. lodine and iodine compounds. In: Block SS (ed). Disinfection, Sterilization, and Preservation. Philadelphia: Lea \& Febiger, 1991:152-66.

20. Pelletier JS, Tessema B, Westover J, et al. In vitro efficacy of povidone-iodine nasal and oral antiseptic preparations against severe acute respiratory syndrome-coronavirus 2 (SARS-COV-2). medRxiv. 2020.05.25.20110239.
21. Panchmatia R, Payandeh J, Al-Salman R, et al. The efficacy of diluted topical povidone-iodine rinses in the management of recalcitrant chronic rhinosinusitis: a prospective cohort study. Eur Arch Otorhinolaryngol. 2019;276:3373-81.

22. Kanagalingam J, Feliciano $\mathrm{R}$, Hah JH, et al. Practical use of povidone-iodine antiseptic in the maintenance of oral health and in the prevention and treatment of common oropharyngeal infections. Int J Clin Pract. 2015;69:1247-56.

23. Yoneyama A, Shimizu M, Tabata M, et al. In vitro short-time killing activity of povidone-iodine (Isodine Gargle) in the presence of ora organic matter. Dermatology. 2006;212(Suppl. 1):103-8.

24. Ito $\mathrm{H}$, Ito T, Hikida $\mathrm{M}$ et al. Outbreak of highly pathogenic avian influenza in Japan and anti-influenza virus activity of povidone-iodine products. Dermatology. 2006; 212(Suppl. 1):115-18.

25. Satomura K, Kitamura T, Kawamura T et al. Prevention of upper respiratory tract infections by gargling: a randomized trial. Am J Prev Med. 2005;29:302-7.

26. Ogata J, Minami K, Miyamoto H, et al. Gargling with povidone-iodine reduces the transport of bacteria during oral intubation. Can J Anaesth. 2004;51:932-6

27. Seguin P, Tanguy M, Laviolle B, et al. Effect of oropharyngeal decontamination by povidone-iodine on ventilator-associated pneumonia in patients with head trauma. Crit Care Med. 2006;34:1514-9.

28. Mundipharma Pharmaceuticals Pte Ltd. BETADINE ${ }^{\circledR}$ Gargle \& Mouthwash. Available at: http://sg.betadine.com/en/sg/cold-andflu/betadine-gargle-and-mouthwash (accessed July 21, 2020).

29. Mundipharma Pharmaceuticals Pte Ltd. BETADINE ${ }^{\circledR}$ Sore Throat Spray. Available at: http://sg.betadine.com/en/sg/cold-and-flu/ betadine-sore-throat-spray (accessed July 21, 2020) 